SYNYCHKIVYURII,

Melitopol State Pedagogical University of B. Khmelnytsy (Melitopol, Ukraine)

e-mail:venok95@bk.ru,ORCID0000-0002-2661-1462

\title{
RESOURCE OF PALEOLITHIC ARTEFACTS OF LOWER DNIEPER
}

This paper describers the state of archaeological resource of Paleolithic artefacts in the territory of the Lower Dnieper. The places, discovery dates, the names of the researchers conducted excavations are presented. According to the aim of the issue, the general description of the history of Palaeothic artefacts of Lower Dniper is presented. The analysis of the representational historiographic base of the issue gave an opportunity to discover the first scaled study provided by Gornostaevskaya archeological expedition in the region in 1950-s which was connected with Kachovskyi's reservoir building. The later studies were performed by Kherson's expedition affiliated to the Institute of Archeology of Ukrainian Academy of Science. During the years of independence some restudies were provided by the enthusiastic scientists, M.P. Olenkovsky's work could be distinguished among them. Approximately thirty and a half stations of Paleolithic Age were found in the region. Unfortunately, the vast majority of the stations were destroyed. The oldest discoveries are presented by the two stations of the Middle Paleolithic Age: the first is situated between the villages of Balky and Blagovishchenko; the second is Rock Orel near Maychka village. The author determines the problems which the Ukrainian researchers face: 1) the vast majority of the stations are destroyed by the waters of Kachovka's reservoir or the soil reclamation works; 2) the problem of artefacts' final dating; 3 ) the lack of finance of the scientific institutions which has a negative influence on the further studies.

Key words: Paleolithic resources; Lower Dnipro; archaeological research.

\section{Introduction}

The actuality of a theme is conditioned of the necessity of historiography generalization of scientific works which light up research of the archaeological artefacts on the territory of Ukraine. It is necessary as the historiographical studies allow us to see clearly all plenitude of the problems of archaeological science, and select from them the most essential and perspective ones. If to describe and study the developmental process of archaeological science on every region separately, combine information of these studies together, it is possible to reproduce the integral picture of a process of archaeological study, which facilitates to reveal the problems and prospects of this industry of scientific knowledge. The insufficient attention was payed to the domestic historiography's tradition, to the questions of historical and archaeological studies of regions, for instance: this position keeps Natalia Bulyk (2006), Sergiy Vovkodav and Olexandr Yurchenko (2013), I. A. Tseunov (2015). Another problem is cultural-chronological attribution, which is highlighted in the V. N. Stepanchuk's (2006) paper "The Lower and Middle Paleolithic of Ukraine: a chronological framework", and I. A. Tseunov's PhD thesis: "The study of the Paleolithic of Ukraine's mainland in the last third of XIX - the first half of the XX century (2018)".

The Lower Podniprov'ya is not an exception, as summarizing historiography analysis of the archaeological studies is not enough and it has been produced long ago. The last study dated 1991 (Olenkovskyi M.P., 1991), the earlier performed in 1968 (Stanko V. N., 1971).

Moreover, the history of Paleolith's studies of this region is predominantly interesting for having the rich cultural archaeological material, which permits to reveal the history of creation and a culture of particular ethos, its spiritual and sacral world. In this context everything depends on the state of a resourceful base and physical condition of archaeological artefacts. The region of lower flow of Dnieper creates an idea of national picture of Paleolith's culture. Consequently, the development of this issue appears as a component for establishing an integral picture of archaeological works of domestic researchers. It is a significant part of scientific and theoretic value of the work. Adding to abovementioned, the research materials can be used for preparation of summarizing works from the history of domestic archaeology, history of Ukraine, and in historical and regional editions' writing.

The purpose of the article is to summarize the description of history of studies of Paleolithic artefacts of Lower Dnieper. The objectives are to present the integral picture of study and highlight the urgent problems.

\section{Methods}

Two fundamental principles of historical research are the basis: scientific objectivity and historicism. In addition, historical-chronological, comparative-historical, syntax and induction methods are used.

\section{Results and Discussion}

Analyzing the historiography of this topic, we can find that one of the first big studies in the region is conducted in connection with the building of the Kakhovka's Reservoir, Gornostaevka's archeological expedition in the 1950 years. The further studies were performed the Kherson's expedition of the Institute of Archeology of the Academy of 
Sciences of Ukraine. Especially, the significant work of Mykola Olenkovsk (1992) should be mentioned in the context who has conducted it from the mid-1970-s to the present day. He began the excavations of the artefacts from the Stone Age near the bottom basin of Dnieper and in the North Azov (the coast of the Gulf of Sivash) territory, which has remained undiscovered to that time.

Researcher's materials published in several books and papers in which he outlined his vision of cultural. Also explored here Y.F. Levytskyi (1949), D.Ya. Telehin (1961), V. N. Stanko (1971), S.V. Smyrnov, (1971), I.I. Boryskovskyi and N.D. Praslov (1964). The result of these works is presented by the rich resourceful base, which includes approximately thirty-half dozen local and Stone Age's artefacts found. The result of these works has been a rich resourceful base, which includes individual articles and references in summaries, collections, history, archeology and local history books, thematic collections of local educational institutions and societies. Such regional subjects are insufficiently highlighted, consequently, in this context this article is an attempt to summarize the historical process of archaeological research of artefacts described by the above-mentioned scholars.

As a result according to archaeological studies, one of the first was opened a station in the village of Cairo Gornostaevsky district in 1953, it was explored by Dmitri Telegin, near the settlement, in a ravine called Merzlyakov's gully, he found the station of the Upper Paleolithic period. It was re-examined by a researcher in 1957, after the reservoir was filled. More than hundred silicon Paleolithic tool were collected - 5 nucleuses, 6 scrapers, 5 burins, several pieces of billets for the tool, industrial waste products in 1953, on the slope of the left horn of the Merzlyakova gully, and in 1957 in the erosion of the forest shore. The age of the artifacts was determined within 15-11 thousand years according to the form of the tools and technique of silicon's processing (Telegin, 1961).

Moreover, there was a station of the Middle Paleolithic period in Vasilivskyi district, between the villages of Balky and Blagovishchenko discovered in the 50-s of the XX century. It was explored by I. P. Savovskyi, A. V. Bodianskyi, Yu. G. Kolosova, O. V. Tuboltsev.

Several Paleolithic stations were opened near Maiachka village in the district in the 60 -s of the XX century:

1. Balka Osokorovka1,3,4 the site of the Upper Paleolithic age was excavated by Levytskyi I. F., Bodianskyi A. V. (Levytskyi, 1949);

2. Rock Orel the location of the Middle Paleolithic Age, was excavated by Bodianskyi A. V in 1955 - 1956-s (Bodianskyi, 1960);

3. Station "Kruhlyk" Midlle Paleolithic Age was excavated by Danelenko V. N. (Danelenko, 1949);

4. Balka Kapustiana the location of the Upper Paleolithic Age was excavated by Bodianskyi A. V. in 1952 (Bodianskyi, 1993);

5. The location of the Upper Paleolithic Age was excavated by Smyrnov S. V. in 1968 (Smyrnov, 1971);

6. Balka Snihurova stables of the Paleolithic Age was excavated by Nuzhnyi D. Yu. (Telegin, Bodianskyi, 1961).

In addition to the aforementioned, three stations were discovered in Lyubimivka village, Kakhovskyi district, Kherson region in 1968. It was explored the paleolithic sector of the Kakhovka archaeological expedition led by V. Stanko. The first was found in the southern outskirts of the village, 142 artifacts of silicon goods were found here on the erosion of the forest shore, a digging prospect holes showed that the cultural layer was not preserved, and some findings were located at a depth of 40 centimeters to 4 meters (Stanko, 1971).

"Liubymivskyi Beach" was the station of the Upper Paleolithic Age, which was located at $150 \mathrm{~m}$ to the west of the Somova's ravine, opposite to the center of the village. It was opened by V. Stanko in 1968. In 1976, 1978-1984, 1989 year he was examined by Nikolai Olenkovsky. In 1968 and 1980 there was digging prospect holes. About 150 silicon goods of an age of more than 20 thousand years were found. At the beginning of 1990-s a station was completely destroyed by reservoir's waters. The last station of the Upper Paleolithic age was "Somova Balka" located at $0.4 \mathrm{~km}$ to the north-east of the village. The silicon material of the Upper Paleolithic Age is numerous, more than 1200 copies, the age of the station was about 15-13 thousand years BC (Olenkovsky, 2004).

The two stations of the Upper Paleolithic Age were discovered in the Sofiivka village, Kakhovka district. The first - "Sofiivka" was located at $1.0 \mathrm{~km}$ to the west of the village. Opened at the end of the 1960-s by the Kakhovka's expedition of the Institute of Archeology of Academy of Sciences of Ukraine. The small collection of the silicon tools was found in the reservoir's erosion. It is not survived to the present time. The second station "Velyvalska Balka" of the Upper Paleolithic Age was located at $4 \mathrm{~km}$ to the west of the village. Stanko opened it in 1968. In 1978-1981 Olenkovskyi Mykola conducted the additional collecting of archaeological material on the erosional bank. It was obtained the numerous collection of the silicon tools (more than hundred items). The station was completely destroyed by the waters of the reservoir (Olenkovsky, 2004).

In 1973 year Mykoloiu Olenkovsky opened a new station "Vasylivskyi Vystup I" of the Upper Paleolithic Age located at $0.4 \mathrm{~km}$ to the south-west of Vasylivka village Kakhovka district. It was investigated by Nikolai Olenkovsky in 19781981, 1984, 1989, 1995. The stoned archaeological material was collected along a coast line of Kakhovsky's reservoir, which had a length $300 \mathrm{~m}$. The numerous founding testified human presence there in Paleolithic and Neolithic Age. It was completely destroyed by Kakhovsky reservoir (Olenkovsky, 2004).

1974 year was fruitful for the domestic scientists who found a few stations, for example: In the Zavodivka village of Gornostaevsky district, the Paleolithic station was discovered station - Zavodivka II of the Upper Paleolithic Age, which located at a distance of $2.2 \mathrm{~km}$ to the north of the village, explored by Mykola Olenkovsky in 1974. Some silicon goods were collected on the eroded shore of Kakhovka's Reservoir (Bodianskyi, 1960).

Several Paleolithic stations were found in the already known Cairo village - "Cairo II" station of the Upper Paleolithic Age opened by Mykola Olenkovsky. It was located near the northern outskirts of the village. There were several silicon tools on the eroded shore, including a typical endscraper for the arrowhead of the late Paleolithic Age. The station (Cairo III) of the Upper Paleolithic Age was located at $0.3 \mathrm{~km}$ to the north of the village. It was opened by Mykola Olenkovsky in 1974. He continued to investigate it in 1975$1988,1995,2001$. More than four thousands of silicon items were collected on the eroded banks. It was supposed that they were related to the end of the Upper Paleolithic Age to about 15-11 thousand BC (Olenkovsky, 2005).

Mykoloiu Olenkovsky was opened Leontievka's station of the Upper Paleolithic Age in Mykhailivske village, Novovorontsovsoho district, the Kherson region. The station has two layers; the lower layer is cultural one and represents the remains of the Upper Paleolithic Age. It was 
investigated by the excavation's trench and two prospect trenches in the area of $38 \mathrm{~m}^{2}$. A large collection of the archaeological material has about 1600 silicon tools. The station lot belongs to the Osokor archaeological culture. According to the geological data, it can be synchronized with the warming phase of Allred. Radiocarbon Date is approximately - $12150 \pm 90$ (Ki-6201) (Olenkovsky, 2004).

A location of the Upper Paleolithic Age was found in Pokazne vilage, Mykhailivskyi district, "Kashtaieva Balka" in 1975. It was excavated by Mykhailov B. D. (Mykhailov, 1987).

In 1976 a station "Liubymivka III" of the Upper Paleolithic Age was found in the Liubymivka village. It was located on the shore within the village at $1.3 \mathrm{~km}$ to the west of Somova ravine. It was investigated in 1978-1983, 1987, 1989, 1990, 1996, 2000, 2003 by Nikolai Olenkovsky. The rich archeological material (about 600 items) was collected to the mid-1990-s. The station was completely destroyed by the reservoir. The age of the monument is $16-14$ thousand years BC (Olenkovsky, 2004).

1978 was also rich in opening. In particular, a station "Vasylivskyi Vystup II" of the Upper Paleolithic Age was opened, which located on the opposite of the north-east of the village. It was investigated by Olenkovsky in 1979-1981, 1984, 1989, 1995, 2000. The silicon goods are collected at a distance of up to 100 meters along the shore, nowadays it is completely destroyed by the coastal abrasion (Olenkovsky, 2004).

Almost a dozen places of primary residents were found in the Liubymivka village the same year:

1. "Station Liubymivka" of the Upper Paleolithic Age settled opposite to the central part of the village. It was opened by Olenkovsky in 1978 and investigated in 19791985. More than 700 silicon goods were collected in coastal erosions. The station was almost completely washed by Kakhovka's reservoir, its remains were destroyed by the work of the coastal strengthening in the 1980-s. It was dated by $26-23$ thousand years BC;

2. Station "Liubymivka II" of the Upper Paleolithic Age was located near the eastern outskirts of the coastal part of the village. It was excavated by M. Olenkovsky in 1978, in the erosion of the left bank of the Somova ravine. There a silicon item was found;

3. Station "Liubymivka IV" of the Upper Paleolithic Age was located at $1.5 \mathrm{~km}$ to the east of a village. It was opened by M. Olenkovsky in 1978 and investigated in 1979-1984, 1989. Archaeological material is comprised of about four hundred items. At the beginning of the 1990-s, it was completely destroyed by a reservoir and coastal reinforcements. The age of the artefacts was approximately $26-23$ thousand years $\mathrm{BC}$;

4. Station "Liubymivka VI" of the Upper Paleolithic was located at $2.5 \mathrm{~km}$ to the west of the Somova ravine and was opposite to the village. It was opened by Olenkovsky in 1978. About ten silicon items were found in the banks' erosions;

5. Station "Liubymivka VII" of the Upper Paleolithic Age was located at $3 \mathrm{~km}$ to the east of a village. It was opened by Olenkovsky in 1978, investigated in 1979-1984, 1989. Approximately three dozen silicon items were found there. It was completely eroded of the reservoir's waters before 1980 (Olenkovsky, 2004).

In 1979 a station "Chornianskyi Pod"of the Upper Paleolithic Age was found in the Chornianka village, the Kakhovskyi district, which was located on the north-western slope of the coast of the pond at $0.7 \mathrm{~km}$ from a village. It was opened by J. Gershkovich. In 1982 and 1983 it was examined by Olenkovsky. More than a dozen silicon items were collected. The excavations have not been investigated yet and it has not been taken under the state protection (Olenkovsky, 2004).

In the 1981 Mykoloiu Olenkovsky opened a station "Vasylivskyi Vystup IV" of the Upper Paleolithic Age which was located to the opposite of a village's center. Some silicon items were found on the eroded shore banks. Unfortunately, it has not been preserved to the present (Olenkovsky, 2004).

1981 brought much more discoveries, namely two stations of Paleolithic Age were opened in the Cairo village, Gornostaevsky dist: the first of them "Cairo IV" of the Upper Paleolithic Age was discovered by Olenkovsky, and situated opposite to the south part of a village. Several silicon items were found on the eroded bank. The next was Station "Cairo V" of the Upper Paleolithic Age situated along the shores of the Kakhovka's Reservoir where several silicon items were collected (Olenkovsky, 2005).

Two Paleolithic stations were found in the village Zmiivka of Beryslav district: the first of them was "Drimailivska Balka I" situated on the left bank of Drimailivska gully, at a distance of $0.5 \mathrm{~km}$ from the entrance to the Dnieper valley, at $3 \mathrm{~km}$ to the west of a village. It was opened by Olenkovsky in 1981. About a dozen patinated items of the Upper Paleolithic Age were collected on the eroded banks, there were a burin and chisel among them. The second station Drimailivka II was located on the right bank of the river Dnieper, at $1.8 \mathrm{~km}$ to the west from a Zmiivka village. It was opened by M. Olenkovsky in 1981. The archaeological material was collected on the eroded banks of the second terrace in the valley of Dnieper. The silicon items consisted of a core, a combined tool (scraper-cutter), a scraper tip on the bladelet, bacet microbladelet, a retoucher, bladelets and flake (Olenkovsky, 2005).

A station "Novokairska Balka" was found in the Beryslav district in the Respublikanets village, it was located on the left bank of the Novokairska ravine, at $2 \mathrm{~km}$ from its entrance into the valley of Dnieper, at $1.5 \mathrm{~km}$ to the west of a village. It was discovered by Olenkovsky in 1981. About a dozen patinated items were collected on the eroded banks. There were a plate with retouched truncation, a plate with odliqe, bladelet and flake among the findings (Olenkovsky, 2007).

Two stations were explored in the Vasilivka village in Kakhovka district: the first was "Shyrokyi Mys I" of the Upper Paleolithic Age, which was located at $2 \mathrm{~km}$ to the north of a village. It was opened by Olenkovsky in 1981 and investigated in 1984 and 1995. The material was collected on the eroded left bank of Kakhovka's reservoir. Paleolithic silicon items were found at the depth of 40 meters along the cliff. They were not preserved in 2004. The second station was "Shyrokyi Mys II" of the Upper Paleolithic Era which was located at $0.2-0.3 \mathrm{~km}$ to the south of "Shyrokyi Mys I". It was opened by Olenkovsky in 1981, was investigated in 1984 and 1995. A few archeological items were collected on the eroded banks which were not preserved to the current time (Olenkovsky, 2004).

A station "Dmitrovka" of the Upper Paleolithic Age was found in Dmitrovka village of Kakhovsky district the following 1982. The national station was taken under the state protection. It is located $80 \mathrm{~m}$ to the north of a village on a small elevation's adjacent to the modern right bank of Kashhanak's ravine, $5 \mathrm{~km}$ from the entrance to "Pod Zelenyi". It was opened by the local researches in 1982. It was investigated during the excavations in 1986, 1987, 1990, 2000, 2001 and in 1985-2001, 2004 by Olenkovsky. 
It is a two-layered station. The lower cultural layers represent the remains of the Upper Paleolithic station. There are some grounds to consider it as a place of repeated visits by hunters during a short period of time. It was investigated by the excavations on the area of $205 \mathrm{~m}^{2}$. The archaeological material presents a numeral collection of silicon items, tools made of various rock, hawk, and remains of fauna. The silicon items are presented by more than 5800 goods. There are 142 nucleuses and 849 tools with the secondary processing among them. Up to $25 \%$ of them are represented by the plates and microblades. About $60 \%$ of them are represented by splits without any additional processing. The tools with the secondary processing are quite diverse: scrapers, incisors, flakes and blades, microblades micronetized plates, adzeled tools, punctures, plates and scraps with grooves, plates with straight-right or cut-off ends, combined implements, plates and scraps with retouch. Separate items are represented by products of Marion, quartzite, talc, shale, granite and sandstone. Up to a dozen of pebbles from dense dark yellow sandstone of the Dniester origin were detected. The faunal remains belonged to a bison and a horse according to O. Sekerskaya. They are referred to the Lower Dnipropian Epigravite culture. Radiocarbon dating is about $16520 \pm 95$ (KI-5826). The part of the station was destroyed by the construction of a pond in the channel beam (Olenkovsky, 2004).

A station - "Kakhovka I" of the Upper Paleolithic Age was opened in Kakhovka town in 1985 which was located to the east of a town. It was investigational by the Kherson's expedition of the Institute of Archeology of the Ukrainian Academy of Science. Approximately dozen silicon items were collected (Olenkovsky, 2004).

A station "Liubymivka X" of the Upper Paleolithic Age was opened in the Liubymivka village Kakhovsky district in 1986. It was located opposite to the western outskirts of a village. It was opened by the Kherson's expedition of the Institute of Archeology of the Ukrainian Academy of Sciences in 1986. About a dozen silicon items were collected (Olenkovsky, 2004).

A station "Drimailivska Balka II" was opened in 1990, which was located on the left bank of the Drimailivska gully, at $1.0 \mathrm{~km}$ from the entrance to the valley of Dnieper. It was opened by Olenkovsky and Samarom. Approximately two dozen of patinated items of the Upper Paleolithic Age were collected on the eroded forest banks. Some discoveries were found at the depth of $1 \mathrm{~m}$ in the forest. The silicon items were presented by a nucleus, a combined tool (scraper-cutter), a scraper tip on the plate, adzeled tools, blade edge, a retoucher, blades and flake (Olenkovsky, 2007).

A station Mira near the village of Kanivskoe Zaporizhzhya region is one of the most widely investigated. It was excavated by Pisariev I. B. in 1995. In 2000 the members of Zaporozhye Paleolithic expedition of the Union of archaeology and anthropology the Department of Archeology of Stone Age, the Institute of Archaeology of the National Academy of Science of Ukraine made excavations there (Stepanchuk, V.N., Koen, V.Yu., 2001).

It is also worth mentioning the state of chronological dating. The modern scientists solve the problem of chronology of the stations by correlating data of relative and absolute dating, which are obtained by different methods, for example, stratigraphy and geomorphology (geological method), tree-ring dating method, palynological (spore-pollen method), paleontological, methods of geophysics, etc.
A Radiocarbon dating, K-Ar dating, U-Pb dating and others are applied to the absolute dating. They do not give a completely accurate date separately, however only a combination of their results, provides the most accurate date of an object.

The chronological and periodization charts, which featured monuments of the region from the 1950-s to the mid-1980-s, were based on the typology of silicon items, consequently the majority of the artefacts had no clear geological definitions as well as the absolute dates (Smyrnov, 1971; Stanko, 1971).

The trend has changed since the mid-1980-s, when dating specified by the data of geology and the radiocarbon dating. The process was intensified in the $90-\mathrm{s}$ of the XX century. In general, the correction and modification of the dating has been provided until nowadays. In practice, this was shown, for example, for the group of monuments of the Lower Dnieper and the coast of the Gulf of Sivash, which had no absolute dates, as a result they received 10 dates $14 \mathrm{C}$ in the Kiev's laboratory (Olenkovsky, 1999). Moreover, a station "Mira" is provided by stratigraphy definitions and a series of absolute dates (Stepanchuk, 2004).

\section{Conclusions}

Thus, there is a fairly rich archaeological heritage in the lower flows of the Dnieper, namely there are three and a half dozen of Paleolithic stations. The oldest discoveries are two stations of the Middle Paleolithic Age: the first is a station of the Middle Paleolithic period situated between the villages of Balky and Blagovishchenko, discovered in the 50-s of the XX century. It was explored by I. P. Savovskyi, A. V. Bodianskyi, Yu.G. Kolosova, O.V. Tuboltsev. The second is Rock Orel of the Middle Paleolithic age. It was excavated by A.V. Bodianskyi in 1955 - 1956.

Furthermore, the development and calibration of dating techniques for these stations is in the process. Analyzing the history of the study of these stations, the author has identified a number of problems, the main of which is that most of them are currently destroyed by the waters of Kachovka's reservoir or the soil reclamation works. However, the discovered archaeological material is presented in the museums.

It should be mentioned that the excavations were not begin in the region as a hydroelectric station ought to be constructed. Contrary, a reservoir of the hydroelectric station flooded the excavation places and possibly the unknown stations.

The other problem is the relative dating of the finds, the vast majority of which belongs to the Upper Paleolithic Age, without a clear dating. In addition, the poor impact on the studies is occurred in the lack of funding of the scientific institutions and research expeditions. Furthermore, there are no written records about a location of the ancient and archaic people in this context it is similar to a lottery. Nevertheless, as the history shows, the new discoveries are waiting for the researchers.

\section{REFERENCES}

Bodianskyi, A. V. (1993). Verkhnepaleoliticheskoye poseleniye u balki Kapustyanoy. Naukovi pratsi istorychnoho fakultetu. Issue 1: 3-7. (In Rusian)

Bodianskyi, A. V. (1960). Must'yerskaya stoyanka u skaly Orel. KSYA. Issue 9, Vol. 26: 118-121. Retrieved from http:// www.vgosau.kiev.ua/load_period-sb/ksiau_09.pdf (In Russian)

Bulyk, N. (2006). Z istoriyi arkheolohichnykh doslidzhen u Skhidniy Halychyni $v$ XIX - na pochatku XX st. Materialy $i$ dos- 
lidzhennya z arkheolohiyi Prykarpattya i Volyni. Issue 10: 298317 (In Ukrainian)

Vovkodav, Serhiy and Yurchenko, Oleksandr (2013). Istoriya doslidzhen arkheolohichnykh pamyatok Pereyaslavshchyny: istoriohrafichnyy aspekt. Ukrayinskyy istorychnyy zbirnyk, Issue 16. (In Ukrainian)

Danylenko, V. N. (1949). Kruhlyk - the first Lower Paleolithic station of the Lower Dnieper. AP URSR. Issue 2, Vol. 26: 326-331. Retrieved from http://vgosau.kiev.ua/AP-ADU/AP_1949_02.pdf (In Ukrainian)

Demidenko, Yu. E. (2008). The Early and Mid-Upper Paleolithic of the North Black Sea region: an overview. Quartar. Vol. 55: 99114. Retrieved from http://www.quartaer.eu/pdfs/2008/2008_demidenko.pdf (In English)

Dolukhanov, P. \& Sokoloff, D. \& Shukurov, A. (2001). Radiocarbon Chronology of Upper Paleolithic Sites in Eastern Europe at Improved Resolution. Journal of Archaeological Science, Vol. 28, issue 7: 699-712. DOI: https://doi.org/10.1006/jasc.2000.0579 (In English)

Levytskyi, Y. F. (1949). Rozkopky paleolitychnoyi stoyanky na baltsi Osokorovtsi v 1946 r. Arkheolohichni Pamyatky. Issue 2, Vol. 26: 289-291. Retrieved from http://vgosau.kiev.ua/AP-ADU/ AP_1949_02.pdf (In Ukrainian)

Mykhailov, B. D. (1987). Pershe podove pizniopaleolitychne mistseznakhodzhennya v Pivnichnomu Pryazovyi. Arkheolohiya. Vol. 59: 47-52. (In Ukrainian)

Olenkovsky, M. P. (1999). Istoryko-kulturnyy ta khronolohichnyy aspekty piznioho paleolitu pivdnya Ukrayiny. Archaeological Collection of the Kherson Regional State Inspection for the Protection of Monuments. 1: 17-19. (In Ukrainian)

Olenkovskyi, M. P. (1991). Pozdniy paleolit i mezolit Nizhnego Dnepra. Kherson: Ailant, 202 p. (In Russian)

Olenkovskyi, M. P. (1992). Pamyatky doby paleolitu. Archaeological map of the Lower Dnieper area. 1: 63 p. (In Ukrainian)

Olenkovskyi, M. P. (2004). Arkheolohichni pamyatky Kakhovskoho rayonu Khersonskoyi oblasti. Archaeological map. Kherson: Ailant, 72 p. (In Ukrainian)

Olenkovskyi, M. P. (2005). Arkheolohichni pamyatky Gornostaivskogo rayonu Khersonskoyi oblasti. Archaeological map. Kherson: Ailant, 68 p. (In Ukrainian)

Olenkovskyi, M. P. (2007). Arkheolohichni pamyatky Berislavskogo rayonu Khersonskoyi oblasti. Archaeological map. Kherson: Ailant, 108 p. (In Ukrainian)

Olenkovskyi, M. P. (2006). Arkheolohichni pamyatky Novovorontsovskogo rayonu Khersonskoyi oblasti. Archaeological map. Kherson: Ailant. (In Ukrainian)

Olenkovskyi, M. P. (2005). Arkheolohichni pamyatky Novoi Kakhovky. Archaeological map. Kherson: Ailant, 24 p. (In Ukrainian)

Sapozhnikov, I. (2005). Khronolohiya i periodyzatsiya piznioho paleolitu pivdnya Skhidnoyi Yevropy. Materialy $i$ doslidzhennya $z$ arkheolohiyi Prykarpattya $i$ Volyni. Issue 9: 14-31. Retrieved from http://www.inst-ukr.lviv.ua/files/09/2Sapozhnikov.pdf (In Ukrainian)

Smyrnov, S. V. (1971). Nove pizniopaleolitychne mistseznakhodzhennya v Nadporizhzhi. Arkheolohichni doslidzhennia $v$ Ukraini v 1948 r. Issue 3. (In Ukrainian)

Stanko, V. N. (1971). Razvedki paleolita na Nizhnem Dnepre. Arkheolohichni doslidzhennia v Ukraini v 1968 year. Issue 3. Kyiv: Naukova dumka: 105-108 (In Russian)

Stepanchuk, V. (2006). Nyzhniy i seredniy paleolit Ukrayiny: khronolohichni ramky. Antropolohichnyy typ nosiyiv kultury, osnovni mistseznakhodzhennya reshtok vykopnykh liudey. Materialy $i$ doslidzhennya $z$ arkheolohiyi Prykarpattya $i$ Volyni. Issue 10: 1749. (In Ukrainian)

Stepanchuk, V. N. (2004). Stoyanka Mira v Srednem Podneprovye: $\mathrm{k}$ voprosu o gomogennosti paleoliticheskikh sloyev $\mathrm{v}$ epokhu mamontov. Stratum plus. 1: 187-205. (In Russian)

Stepanchuk, V. N. and Koen, V. Yu. (2001). Raboty na stoyanke
Mira pod Zaporozhyem v 2000 g. Arkheolohichni doslidzhennia v Ukraini 1999-2000 rr: 221. (In Russian)

Telehin, D. Ya. (1961). Slidy epipaleolitu ta neolitu na Nyzhniomu Podniprovyi. Arkheolohichni Pamiatky URSR. Vol. 10. Retrieved from http://vgosau.kiev.ua/AP-ADU/AP_1961_10.pdf (In Ukrainian)

Telehin, D. Ya. and Bodianskyi, A. V. (ed.) (1990). Spysok arkheolohichnykh pamyatok Dniprovskoho Nadporizhzhya (Dnipropetrovska i Zaporizka oblasti). Kyiv, 32 p. (In Ukrainian)

Toshchev, G. N. and Yelnikov, M. V. and Drovosekova, O. V. (2003). Drevnosti Zaporozhskogo kraya (Materialy k svodu pamyatnikov istorii $i$ kultury). Zaporozhye. (In Russian)

Tseunov, I. (2015). Poliovi doslidzhennya paleolitu pivdnya Ukrayiny novobudovnymy ekspedytsiyamy u 20-30-kh rr. XX st. Materialy i doslidzhennya z arkheolohiyi Prykarpattya $i$ Volyni. 19: 307-312. (In Ukrainian)

Tseunov, I. (2018). Doslidzhennya paleolitu materykovoyi Ukrayiny $v$ ostanniy tretyni $X I X-$ pershiy polovyni $X X$ st. Thesis PhD: 07.00.04. Kyiv, Retrieved from http://chtyvo.org.ua/authors/ Tseunov_Ihor/Doslidzhennia_-paleolitu_materykovoi_Ukrainy_v_ostannii_tretyni_KhIKh__pershii_polovyni_KhKh_st/ (In Ükrainian)

\section{LIST OF REFERENCE LINKS}

Бодянский А. В. Верхнепалеолитическое поселение у балки Капустяной. Наукові праці історичного фракультету. Запоріжжя, 1993. Вип. 1.С. 3-7.

Бодянский А. В. Мустьерская стоянка у скалы Орел. Краткие сообщения Института Археологии. 1960. Вип. 9. С. 117. URL: http://www.vgosau.kiev.ua/load_period-sb/ksiau_09.pdf (Дата звернення: 19.03. 2019)

Булик Н. 3 історії археологічних досліджень у Східній Галичині в XIX - на початку XX ст. Матеріали і дослідження 3 археології Прикарпаття і Волині. 2006. Вип. 10. С. 298-317.

Вовкодав С., Юрченко О. Історія досліджень археологічних пам'яток Переяславщини: Історіографічний аспект. Український історичний збірник. 2013. Вип. 16.

Даниленко В. Н. Круглик - перша нижньопалеолітична пам'ятка УРСР. Археологічні пам'ятки УРСР. 1949. Т. 2. С. 326331. URL: http://vgosau.kiev.ua/AP-ADU/AP_1949_02.pdf (Дата звернення: 11.03.2019)

Левицкий И. Ф. Розкопки палеолітичної стоянки на балці Осокоровці в 1946 р. Археологічні пам'ятки УРСР. 1949. Т. 2. C. 289-291. URL: http://vgosau.kiev.ua/AP-ADU/AP_1949_02.pdf (Дата звернення: 16.02.2019)

Михайлов Б. Д. Перше подове пізньопалеолітичне місцезнаходження в Північному Приазов'ї. Археологія. 1987. Т. 59. C. $47-52$.

Оленковский Н. П. Поздний палеолит и мезолит Нижнего Днепра. Херсон, 1991. 202 с.

Оленковський М. П. Археологічні пам'ятки Бериславського району Херсонської області. Археологічна карта. Херсон: Айлант, 2007. 108 с.

Оленковський М. П. Археологічні пам'ятки Горностаївського району Херсонської області. Археологічна карта. Херсон: Айлант, 2005. С. 15-16.

Оленковський М. П. Археологічні пам'ятки Каховського району Херсонської області. Археологічна карта. Херсон: Айлант, 2004. С. 25.

Оленковський М. П. Археологічні пам'ятки Нововоронцовського району Херсонської області. Археологічна карта. Херсон: Айлант, 2006. С. 30.

Оленковський М. П. Археологічні пам'ятки Нової Каховки. Археологічна карта. Херсон: Айлант, 2005. 24 с.

Оленковський М. П. Історико-культурний та хронологічний аспекти пізнього палеоліту півдня України. Археологічна збірка Херсонської обл. держ. інспекції охорони пам'яток. 1999. № 1. C.17-19. 
Оленковський М. П. Пам'ятки доби палеоліту. Археологічна карта Нижньодніпровського регіону. 1992. Вип.1. 63 с.

Сапожников І. Хронологія і періодизація пізнього палеоліту півдня Східної Європи. Матеріали і дослідження з археології Прикарпаття і Волині. 2005. Вип. 9. С. 14-31.

Смирнов С. В. Нове пізньопалеолітичне місцезнаходження в Надпоріжжі. Археологічні дослідження в Україні в 1948 р. Київ: Наук. думка, 1971. Вип. 3.

Список археологічних пам'яток Дніпровського Надпоріжжя (Дніпропетровська і Запорізька області) / Телегін Д. Я. (упор.), Бодянський О. В. (упор.). Київ, 1990. 32 с.

Станко В. Н. Разведки палеолита на Нижнем Днепре. Археологические исследования на Украине в 1968 г. Київ: Наукова думка, 1971. Вып. III. С. 105-108.

Степанчук В. Нижній і середній палеоліт України: хронологічні рамки. Антропологічний тип носіїв культури, основні місцезнаходження решток викопних людей. Матеріали і дослідження з археології Прикарпаття і Волині. 2006. Вип. 10. C. $17-49$.

Степанчук В. Н. Стоянка Мира в Среднем Поднепровье: к вопросу о гомогенности палеолитических слоев в эпоху мамонтов. Stratum plus. 2003-2004. № 1. C. 187-205.

Степанчук В. Н., Коен В. Ю. Работы на стоянке Мира под Запорожьем в 2000 г. Археологічні відкриття в Україні 19992000 рр. Киев, 2001. С. 221.
Телегін Д. Я. Сліди епіпалеоліту та неоліту на Нижньому Подніпров'ї. Археологічні пам'ятки УРСР. Т. 10. Київ: Видавництво АН УРСР, 1961. С. 194-196.

Тощев Г. Н., Ельников М. В., Дровосекова О. В. Древности Запорожского края (Материалы к своду памятников истории и культуры). Запорожье, 2003.

Цеунов І. Польові дослідження палеоліту півдня України новобудовними експедиціями у 20-30-х рр. XX ст. Mатеріали і дослідження з археології Прикарпаття і Волині. 2015. Вип. 19. С. 307-312.

Цеунов І. А. Дослідження палеоліту материкової України в останній третині XIX - першій половині XX ст.: дис. ... к.і.н.: 07.00.04. Київ, 2018. URL: http://chtyvo.org.ua/authors/Tseunov_Ihor/Doslidzhennia_paleolitu_-materykovoi_Ukrainy_v_ostannii_tretyni_KhIKh_pershii_polovyni_KhKh_st/ (Дата звернення: 14.05.2019)

Demidenko Yu. E. The Early and Mid-Upper Palaeolithic of the North Black Sea region: an overview. Quartar. Vol. 55. Pp. 99114. URL: http://www.quartaer.eu/pdfs/2008/2008_demidenko.pdf (Дата звернення: 25.04.2019)

Dolukhanov P. \& Sokoloff D. \& Shukurov A. Radiocarbon Chronology of Upper Paleolithic Sites in Eastern Europe at Improved Resolution. Journal of Archaeological Science. 2001. Vol. 28, issue 7: 699-712. DOI: https://doi.org/10.1006/jasc.2000.0579

\section{Синичків Юрій,}

Мелітопольський державний педагогічний університет

імені Богдана Хмельницького (м. Мелітополь, Україна)

e-mail:venok95@bk.ru,ORCID 0000-0002-2661-1462

\section{ДОСЛІДЖЕННЯ ПАМ'ЯТОК ПАЛЕОЛІТУ НИЖНЬОГОПРИДНІПРОВ'Я}

У статті розкрито історію досліджень пам'яток доби палеоліту на території Нижнього Придніпров'я. Доцільність написання статті зумовлена тим, що з сучасним розвитком вітчизняної історичної науки зростає необхідність історіографічного узагальнення праць, оскільки подібні дослідження дозволяють чіткіше побачити всю повноту проблем археологічної науки, виділити з них найбільш важливі й перспективні. Відповідно до цього метою статті постає узагальнюючий опис історії дослідження палеолітичних пам'яток Нижнього Придніпров'я. Аїї завданням - формування цілісної картини історії досліджень палеолітичних пам'яток. Аналіз репрезентативної історіографічної бази з даного питання дав змогу з'ясувати, що одні із перших масштабних досліджень в цьому регіоні проведено у 1950-х роках Горностаївською археологічною експедицією у зв'язку із будівництвом Каховського водосховища. Пізніше дослідження провадить Херсонська експедиція Інституту археології АН України, в роки незалежності в основному проводились повторні обстеження знайдених пам'яток та дослідження окремих науковців-ентузіастів, серед яких виділяється робота М. П. Оленковського. До того ж з'ясовується, що в регіоні нараховується близько тридцяти 3 половиною десятка пам'яток доби палеоліту. Чимала кількість пам'яток на сьогодні не збереглась. Найстаршими знахідками є дві стоянки доби Середнього Палеоліту: перша - поміж селами Балки та Благовіщенка; друга - Скала Орел, поблизу села Маячка. Автор акцентує увагу на проблемах, які постають перед українськими дослідниками при вивченні та описі пам'яток палеоліту Нижнього Подніпров'я. Зокрема таких: 1) більшість пам'яток на даний час зруйновані водами Каховського водосховища, чи меліоративними роботами; 2) існує проблема з датуванням знахідок, значну масу 3 них відносять до доби фінального палеоліту, без чіткого датування; 3) негативний вплив на розвиток досліджень має недостатнє фінансування наукових установ та дослідницьких експедицій.

Ключові слова: Нижнє Придніпров'я; археологічні дослідження; палеолітичні пам'ятки.

(c) Synychkiv Yurii

Надійшла до редакції: 12.07.2019

Прийнята до друку: 05.08.2019 